\title{
Pengaruh APGAR family terhadap quality of life pasien diabetes mellitus tipe 2
}

\author{
Feny Tunjungsari ${ }^{*}$, Isbandiyah ${ }^{2}$, Farajihan $^{3}$ \\ ${ }^{1}$ Departemen Kedokteran Keluarga, Fakultas Kedokteran, Universitas Muhammadiyah Malang \\ ${ }^{2}$ Departemen Ilmu Penyakit Dalam, Fakultas Kedokteran, Universitas Muhammadiyah Malang \\ ${ }^{3}$ Pendidikan Dokter, Universitas Muhammadiyah Malang
}

\begin{abstract}
ABSTRAK
Indonesiamerupakan salah satunegara dari 10 negara yang memiliki jumlah penderita diabetes mellitus (DM) terbanyak dengan prevalensi DM di perkotaan sebesar 5,7\%. Menurut Pusat data dan Informasi kesehatan Republik Indonesia, bahwa proporsi diabetes mellitus di Kota Malang sebanyak 2,3\%. Tingginya angka diabetes melitus di Kota Malang ini disebabkan kurangnya penerapanfungsi keluarga dengan baik padapenderita DM tipe 2. Kendala yang timbul yaitu sebagian besar masyarakatmenyepelekanjenis penyakitmetabolik ini sehing ga tidak dapat terdeteksilebih dini. Peran keluargadalam penatalaksanaan penderita diabetes mellitus tipe 2 diyakini memilik ipengaruhterhadap kualitas hidup penderita DM. Tujuan penelitian adalah untuk menganalisis pengaruh fungsi keluargaberdasarkan APGAR family terhadap Quality of Life pasien DM tipe 2. Penelitian ini adalah penelitian observasional analitik dengan pendekatan cross sectional dengan 95 subyek penderita diabetes mellitus tipe 2 yang dipilih melalui Simple Random Sampling. Analisis datamenggunakan uji Spearman. Hasil uji korelasi Spearman diperoleh nilai signifikansi APGAR terhadap Quality of Life sebesar 0,000, yang artinya terdapat hubungan yang signifikan ( $p<0,05)$. Koefisien korelasi APGAR terhadap Quality of Life sebesar 0,930, yang artinya sifat kekuatan hubungan adalah sangat kuat. Dapat disimpulkan adany pengaruh yang sangat kuat (0,000) antara APGAR Family terhadap Quality of Life pasien DM tipe 2.
\end{abstract}

Kata kunci: APGAR keluarga; kualitas hidup; DM tipe 2

\begin{abstract}
Introduction: Indonesia was a countryfrom 10 countries that possesses the most dm prevalence of diabetes mellitus (DM) in urban areas amounting to $5.7 \%$. According to data center and health of the republic of indonesia, that the proportion of diabetes mellitus in the city of malang 2,3\%. The high number of diabetes mellitus in the city of malang is because the lack of the application of the family function well in people with DM type 2. Obstacles arising that is the majority of the community ignore this metabolic types ofdisease so that it cannot be detected earlier.The role offamily in aim diabetics mellitus type 2 believed to have the effect on the quality oflife of sufferers DM. Aim of study: This study aimed to analyze function offamilies according to family APGAR to quality oflife dmpatients type 2. Method: this study used an observational analytic with cross the sectional approach, 95 subjects were were chosen by simple random sampling. Data was analyzed using Spearmantest. Results and Discussions: the results showed a value of significance APGAR against quality of life as much as 0.000, which means there were a significant relation exists $(p<0.05)$. A correlation coefficient APGAR against quality of life as much as 0.93 , which means of the nature of the strength of the relations is very strong. Conclusions: It can be concluded that there is a very strong influence (0.000) between APGAR family against quality of life the patient DMtype 2.
\end{abstract}

Keywords: APGAR family; quality of life; DM type 2.

\footnotetext{
* Kores pondensi penulis:

Nama : Feny Tunjungsari

Instansi: Fakultas Kedokteran, Universitas Muhammadiyah Malang

Alamat : Jl. Bendungan Sutami 188A, Malang, Jawa Timur, Telp.: +62-341-552443/+62-341-582260

Email : feny.tunjungsari@gmail.com
} 


\section{Pendahuluan}

Diabetes melitus (DM) tipe 2 merupakan penyakit kronis yang terjadi akibat gangguan sekresi insulin atau ketidakmampuan sel tubuh dalam menggunakan insulin secara efektif. ${ }^{1}$ DM tipe 2 sering ditemukan pada orang dewasa dengan tingkat prosentase 90\%-95\% kasus dibandingkan dengan tipe diabetes melitus tipe 1 dan gestasional. ${ }^{2}$ Penyakit ini adalah suatu masalah kesehatan yang serius dan merupakan 1 dari 4 penyakit tidak menular yang angka kejadiannya terus bertambah. ${ }^{3}$

Berdasarkan hasil penelitian epidemiologi, tampak adanya kecenderungan peningkatan angka insidensi dan prevalensi DM tipe 2 di berbagai penjuru dunia. WHO memprediksikan adanya peningkatan jumlah penyandang DM tipe 2 di tahun-tahun mendatang. Diprediksikan kenaikan jumlah penderita DM di Indonesia dari 8,4 juta pada tahun 2000 menjadi sekitar 21,3 juta pada tahun 2030. Begitu pula dengan hasil prediksi WHO, International Diabetes Federation (IDF) pada tahun 2009, diperkirakan terjadinya kenaikan kasus penyandang DM dari 7 juta pada tahun 2009 menjadi 12 juta pada tahun $2030 .^{2}$

Indonesia merupakan salah satu negara dari 10 negara yang memiliki jumlah DM terbanyak dengan prevalensi DM di perkotaan sebesar 5,7\%. ${ }^{4}$ Kota Malang merupakan kota di Jawa Timur dengan penderita diabetes melitus yang masuk dalam sepuluh penyakit tidak menular terbanyak yaitu menempati peringkat ke 4 pada tahun 2016. ${ }^{5}$ Tingginya angka diabetes melitus di Kota Malang ini disebabkan kurangnya penerapan fungsi keluarga dengan baik pada penderita DM tipe 2. Kendala yang timbul yaitu sebagian besar masyarakat menyepelekan jenis penyakit metabolik ini sehingga tidak dapat terdeteksi lebih dini.

Peran keluarga berpengaruh terhadap kualitas hidup penderita DM. Dukungan dan kepedulian yang diberikan anggota keluarga terhadap penderita diabetes melitus tipe 2 akan memberikan kenyamanan, perhatian, kasih sayang dan dorongan dalam pencapaian kesembuhan dengan sikap menerima kondisinya. Dampak yang timbul dari penyandang DM yaitu masalah psikologis dan fisik sehingga pentingnya peran keluarga dalam meningkatkan kualitas hidup penderita. ${ }^{2}$

Kualitas hidup didefinisikan sebagai persepsi individu tentang posisi mereka dalam kehidupan pada konteks budaya dan sistim nilai dimana mereka hidup dan dalam kaitannya dengan tujuan, harapan, standar, dan kekhawatiran mereka. Definisi ini mencerminkan pandangan bahwa kualitas hidup mengacu pada evaluasi subjektif yang mana tertanam dalam konteks budaya, sosial, dan lingkungan karena definisi kualitas hidup ini berfokus berdasarkan "persepsi” kualitas hidup responden, melainkan efek dari penyakit dan intervensi kesehatan. Dengan demikian, kualitas hidup tidak hanya disamakan dengan istilah status kesehatan, gaya hidup, kepuasan hidup, keadaan mental, atau kesejahteraan. Pengakuan sifat multidimensional tercermin dalam struktur World Health Organization Quality of Life-100 (WHOQOL-100). ${ }^{6}$

Kualitas hidup merupakan suatu konsep multidimensional yang luas meliputi domain fungsi sehari-hari dan pengalaman subjektif, seperti fungsi fisik, fungsi somatik, pemahaman terhadap kesehatan, fungsi sosial dan peran serta kesejahteraan subjektif. Fungsi sosial ini meliputi interaksi alam keluarga, rekan kerja, teman dekat, hingga komunitas umum. Interaksi sosial dalam keluarga dapat berjalan dengan baik apabila fungsi keluarga dijalankan dengan baik. $^{7}$

Untuk meningkatkan kualitas hidup pasien DM maka dibutuhkan dukungan dari orang lain, khususnya keluarga. Hal ini sejalan dengan studi sebelumnya yang menyatakan bahwa salah satu faktor penguat (reinforcing factors) yang menentukan perilaku kesehatan individu adalah adalah dukungan keluarga. ${ }^{8}$ Dukungan keluarga merupakan sikap, tindakan, dan penerimaan keluargaterhadap penderita yang sakit. Dukungan bisa berasal dari orang tua, anak, suami, istri atau saudara yang memiliki hubungan dekat dengan penderita, dimana bentuk dukungan bisa dalam bentuk 
informasi, tingkah laku tertentu atau materi yang dapat menjadikan individu merasa disayangi, diperhatikan, dan dicintai. ${ }^{9}$

Aspek dukungan keluarga berkaitan dengan kadar glukosa darah dalam mempengaruhi kualitas hidup pasien diabetes mellitus tipe 2. Dukungan keluarga berupa kehangatan, keramahan, dan kenyamanan yang terkait dengan monitoring glukosa, diet, dan latihan yang dapat meningkatkan efikasi diri pasien sehingga mendukung dalam keberhasilan merawat diri sendiri sehingga menghasilkan kualitas hidup yang baik. Dukungan keluarga berpengaruh pada sikap dan kebituhan belajar pasien DM 2 dengan cara menolak atau menerima dukungan baik secara fisik, psikologis, emosional, dan sosial. Pasien DM 2 akan lebih positif mempelajari DM apabila keluarga memberikan dukungan dan berpartisipasi dalam pendidikan kesehatan. ${ }^{10}$

Semakin tidak terkontrolnya kadar glukosa darah, maka regimen pengobatan semakin kompleks dan retriksi terhadap diet meningkat sehingga berpengaruh pada peningkatan insiden depresi dan kecemasan. Dalam hal ini berarti kualitas hidup pasien DM buruk. Selain itu, akibat peningkatan pengelolaan, terjadi pula peningkatan risiko insiden hipoglikemia yang sangat berpengaruh terhadap fungsi fisik seorang penderita DM tipe 2. Hipoglikemia menyebabkan peningkatan aktivitas saraf simpatis sehingga dapat menimbulkan manifestasi tremor, takikardia, dan keringat berlebihan. Selain itu keadaan tersebut menyebabkan penurunan kesadaran yang dapat berakibat fatal yaitu kerusakan otak yang ireversibel. Peran keluarga dalam penatalaksanaan penderita diabetes mellitus tipe 2 diyakini memiliki pengaruh terhadap kualitas hidup penderita DM. Tujuan penelitian adalah untuk menganalisis pengaruh fungsi keluarga berdasarkan APGAR family terhadap Quality of Life pasien DM tipe 2.

\section{Metodologi}

Penelitian ini adalah penelitian observational analitik dengan rancangan cross- sectional. Penelitian ini akan dilakukan di Poli Penyakit Dalam Rumah Sakit Umum di Kota Malang selama 29 hari pada tahun 2019. Populasi dalam penelitian ini adalah semua penderita diabetes mellitus tipe 2 di Poli Penyakit Dalam. Sampel dalam penelitian ini adalah penderita diabetes mellitus tipe 2 usia 2065 tahun dengan jenis kelamin laki-laki dan perempuan. Jumlah sampel sebanyak 95 sampel dan Teknik pengambilan sampel dilakukan secara Simple Random Sampling.

\section{Hasil dan Pembahasan}

Data diperoleh berdasarkan hasil jaw aban kuisioner, yang kemudian diolah sesuai dengan tujuan penelitian untuk mengetahui adanya pengaruh antara fungsi keluarga berdasarkan APGAR family dengan Quality of Life pasien diabetes mellitus tipe 2. Pada tabel 1 menunjukkan bahwa dari 95 responden, rata-rata pasien diabetes melitus tipe 2 diderita oleh pasien yang berusia $>40$ tahun dengan jumlah 89 orang (94\%). Sebagian besar responden berjenis kelamin perempuan 59 orang $(66 \%)$.

Tabel 1. Karakteristik Demografi Pasien DM Tipe 2

\begin{tabular}{lcc}
\hline Variabel & f & \% \\
\hline Usia & & \\
1. <40 tahun & 6 & $6 \%$ \\
2. > 40 tahun & 89 & $94 \%$ \\
Jenis Kelamin & & \\
1. Laki-laki & 36 & $40 \%$ \\
2. Perempuan & 59 & $66 \%$ \\
\hline
\end{tabular}

Tabel 2. Distribusi Variabel APGAR Family

\begin{tabular}{lcc}
\hline Fungsi Keluarga & f & $\%$ \\
\hline Keluarga sehat & 37 & $39 \%$ \\
Keluarga kurang sehat & 50 & $53 \%$ \\
Keluarga tidak sehat & 8 & $8 \%$ \\
Total & 95 & $100 \%$ \\
\hline
\end{tabular}

Berdasarkan data hasil penelitian, diperoleh informasi bahwa dari 95 orang responden yang melakukan kontrol rutin di dan 
terdiagnosis sebagai diabetes mellitus tipe 2 lebih banyak pasien yang tinggal dalam lingkungan keluarga dengan fungsi keluarga yang kurang sehat yaitu dengan jumlah 50 orang dengan prosentase sebesar 53\%, sedangkan keluarga sehat sebesar 39\%, dan keluarga tidak sehat sebesar 8\% (Tabel 2). Sedangkan pada tabel 3, pasien DM lebih banyak yang berasal dari keluarga dengan bentuk extended family dengan persentase sebesar $49 \%$, sedangkan pada bentuk keluarga nuclear family sebesar $37 \%$, dyad family sebesar $8 \%$, dan single parent sebesar 5\%. Selanjutnya pada tabel 4, sebanyak 57 pasien mengalami Quality of Life yang buruk dengan prosentase sebesar 60\%, dan Quality of Life baik sebanyak 38 orang dengan persentase $40 \%$.

Tabel 3. Distribusi Faktor Jenis Keluarga

\begin{tabular}{lcc}
\hline \multicolumn{1}{c}{ Jenis Keluarga } & f & \% \\
\hline Nuclear Family & 35 & $37 \%$ \\
Extended Family & 47 & $49 \%$ \\
Dyad Family & 8 & $8 \%$ \\
Single Parent & 5 & $5 \%$ \\
Total & 95 & $100 \%$ \\
\hline
\end{tabular}

Tabel 4. Distribusi Quality of Life

\begin{tabular}{lcc}
\hline QOL & f & $\%$ \\
\hline Kualitas hidupbaik & 38 & $40 \%$ \\
Kualitas hidupburuk & 57 & $60 \%$ \\
Total & 95 & $100 \%$
\end{tabular}

Tabel 5. Hasil Tabulasi Silang APGAR Family dan QOL

\begin{tabular}{|c|c|c|c|c|c|c|}
\hline \multirow{4}{*}{ QOL } & \multicolumn{6}{|c|}{ Keluarga } \\
\hline & \multicolumn{6}{|c|}{ Kurang } \\
\hline & \multicolumn{2}{|c|}{ Sehat } & \multicolumn{2}{|c|}{ Sehat } & \multicolumn{2}{|c|}{ Tidak Sehat } \\
\hline & $f$ & $\%$ & $f$ & $\%$ & $\mathrm{f}$ & $\%$ \\
\hline \multicolumn{7}{|l|}{ Kualitas hidup } \\
\hline baik & 37 & $100 \%$ & 1 & $2 \%$ & 0 & $0.0 \%$ \\
\hline $\begin{array}{l}\text { Kualitas hidup } \\
\text { buruk }\end{array}$ & 0 & $0.0 \%$ & 49 & $98 \%$ & 8 & $100 \%$ \\
\hline
\end{tabular}

Hasil tabulasi silang pada tabel 5, antara fungsi keluarga berdasarkan APGAR family dan Quality of Life diperoleh 37 orang responden memiliki kualitas hidup baik terklasifikasikan ke dalam keluarga sehat, dan 1 orang diantaranya termasuk keluarga kurang sehat. Selanjutnya, 57 orang dengan kualitas hidup buruk, tidak satupun terklasifikasikan sebagai keluarga sehat, 49 orang termasuk keluarga kurang sehat, dan 8 orang diantaranya termasuk keluarga tidak sehat. Hasil uji korelasi Spearman pada tabel 6 diperoleh nilai signifikansi APGAR family terhadap Quality of Life sebesar 0,000 dimana hal ini berarti terdapat hubungan yang signifikan $(\mathrm{p}<0,05)$. Koefisien korelasi APGAR terhadap Quality of Life sebesar 0,930, yang artinya sifat kekuatan hubungan adalah sangat kuat.

Tabel 6. Hasil Uji Korelasi Spearman

\begin{tabular}{lcc}
\hline \multirow{2}{*}{ Spearman's rho } & \multicolumn{2}{c}{ APGAR } \\
\cline { 2 - 3 } & $\mathbf{r}$ & Sig. \\
\hline QOL & 0,930 & 0,000 \\
\hline
\end{tabular}

Hasil penelitian ini juga sejalan dengan penelitian sebelumnya dimana terjadi penurunan kualitas hidup pasien DM pada semua aspek kehidupan. Dari 8 aspek yang dikaji didapatkan bahwa pada fungsi fisik, emosional, energi, nyeri, kesehatan umum, fungsi sosial perubahan peran akibat masalah fisik, dan perubahan peran akibat masalah emosional mengalami penurunan (semua aspek < 80). ${ }^{11}$ Sebagian pasien merasa tidak mampu melakukan perannya karena merasa gugup, tertekan dan terbebani dengan penyakit yang diderita.

Adanya perubahan peran terjadi karena timbulnya perasaan depresi atau cemas. Kecemasan pasien DM lebih banyak diakibatkan oleh munculnya keluhan diabetes. Penelitian menunjukkan bahwa $47,7 \%$ pasien DM memiliki status kesehatan yang kurang baik jika dibandingkan dengan orang lain. Pasien DM merasa lebih mudah jatuh sakit, dan berpikir kesehatannya akan bertambah buruk. ${ }^{12}$

APGAR Keluarga (Family APGAR) merupakan instrumen penilaian yang digunakan untuk mengukur fungsi keluarga. Instrumen ini menggambarkan lima fungsi pokok keluarga yang meliputi adaptasi, kemitraan, pertumbuhan, kasih sayang dan kekeluargaan. Fungsi adaptasi dapat dilihat berdasarkan tingkat kepuasan 
dalam menerima dukungan yang diberikan selama melalui situasi krisis. Fungsi yang kedua yaitu kemitraan dimana kepuasan dirasakan saat berkomunikasi dan melakukan musyawarah dengan anggota keluarga lainnya dalam hal pengambilan keputusan. Selanjutnya fungsi yang ketiga adalah kepuasan dalam hal kebebasan dalam melewati kematangan individu. Fungsi keluarga berikutnya yaitu kasih sayang dimana kepuasan dirasakan saat memperoleh kasih sayang dalam keluarga melalui rasa saling peduli. Kemudian fungsi keluarga yang terakhir adalah kebersamaan dimana kepuasan dirasakan saat memiliki kebersamaan bersama anggota keluarga yang lainnya. ${ }^{13}$

Studi sebelumnya juga menjelaskan tentang hubungan APGAR keluarga dengan kualitas hidup dimana kesejahteraan secara fisik dan jiwa berhubungan erat dengan rasa puas dengan dukungan yang diterima dari keluarga, kesempatan untuk berbicara, merasakan kasih sayang, puas dengan waktu yang dihabiskan dan dukungan untuk membuat keputusan keluarga. Keluarga disfungsional juga menginterpretasikan adanya konflik yang tumbuh di dalam keluarga dan komunikasi yang kurang. Adanya dukungan keluarga dalam pengambilan keputusan dapat meningkatkan efek positif terkait dengan perawatan. ${ }^{14}$

Keluarga berfungsi untuk mendukung peningkatan kualitas hidup penderita. Kualitas hidup penderita yang baik maka akan mengurangi risiko terjadinya komplikasi penyakit. Studi terdahulu menjelaskan bahwa sebanyak 52,3\% responden memiliki keluarga disfungsional yang sedang dan $43,8 \%$ memiliki keluarga yang sangat fungsional. Hal ini menunjukkan adanya hubungan yang bermakna antara fungsi keluarga dalam meningkatkan kualitas hidup responden ( $\mathrm{p}$ value $=0,014$ ). Selain itu fungsi keluarga juga memiliki pengaruh yang sangat kuat terhadap kualitas hidup penderita $(\mathrm{r}=0,088) .{ }^{15}$

Selain itu, fungsi keluarga dan dukungan sosial berhubungan erat dengan kualitas hidup responden lansia $(\mathrm{p}<0,05)$.
Dalam penelitian ini juga disebutkan bahwa fungsi keluarga yang baik dapat meningkatkan kualitas hidup lansia sehingga lansia dapat melakukan aktifitas dan berperan dengan baik di masyarakat. ${ }^{16}$ Dukungan keluarga merupakan faktor yang paling dominan yang memengaruhi kualitas hidup lansia dengan nilai OR sebesar 5,7. ${ }^{17}$ Kualitas hidup individu yang baik menggambarkan adanya fungsi keluarga yang sangat baik. Sehingga dalam hal ini perlu bagi dokter untuk meningkatkan fungsi keluarga dalam mengelola penyakit yang diderita salah satu anggota keluarganya.

\section{Kesimpulan}

Hasil uji korelasi Spearman diperoleh nilai signifikansi APGAR terhadap Quality of Life sebesar 0,000 , yang artinya terdapat hubungan yang signifikan $(\mathrm{p}<0,05)$. Koefisien korelasi APGAR terhadap Quality of Life sebesar 0,930, yang artinya sifat kekuatan hubungan adalah sangat kuat.

\section{Ucapan Terima Kasih}

Penulis mengucapkan terima kasih atas dukungan responden dan Fakultas Kedokteran, Universitas Muhammadiyah Malang selama penulisan artikel ini.

\section{Referensi}

1. Rahayu KB, Saraswati LD, Setyawan H. Faktor-Faktor Yang Berhubungan Dengan Kadar Gula Darah Pada Penderita Diabetes Melitus Tipe 2. Jurnal Kesehatan Masyarakat [Internet]. 2018 May [cited 2020 Jun 1];6(2):19-28. Available from: https:/ejournal3.undip.ac.id/index.php/jkm/ article/view/20782.

2. Meidikayanti W, Wahyuni CU. The Correlation between Family Support with Quality of Life Diabetes Mellitus Type 2 in Pademawu PHC. Jurnal Berkala Epidemiologi [Internet]. 2017 [cited 2020 Jun 1];5(2):240-252. Available from: http://dx.doi.org/10.20473/jbe.V5I22017.25 3-264.

3. Santoso SB, Perwitasari DA, Faridah IN, 
Kaptein AA. Hubungan kualitas hidup dan persepsi pasien tentang penyakit diabetes mellitus tipe 2 dengan komplikasi. Pharmaciana: Jurnal Kefarmasian [Internet]. 2017 [cited 2020 Jun 1];7(1):33-40. Available from: http://dx.doi.org/10.12928/pharmaciana.v7il .4699 .

4. Mihardja L, Soetrisno U, Soegondo S. Prevalence and clinical profile of diabetes mellitus in productive aged urban Indonesians. Journal of Diabetes Investigation [Internet]. 2013 [cited 2020 Jun 1];5(5):507-512. Available from: https://doi.org/10.1111/jdi.12177.

5. Dinas Kesehatan Kota Malang. Profil Kesehatan Kota Malang Tahun 2017. [Internet]. 2017 [cited 2020 Mar 28]. Available from: https://dinkes.malangkota.go.id/wpcontent/uploads/sites/104/2018/11/ProfilKesehatan-Kota-Malang-Tahun-2017.pdf.

6. Feder K, Michaud DS, Keith SE, Voicescu SA, Marro L, Than J, et al. An assessment of quality of life using the WHOQOL-BREF among participants living in the vicinity of wind turbines. Environmental Research [Internet]. 2015 [cited 2020 Mar 28];142:227-238. Available from: https://doi.org/10.1016/j.envres.2015.06.043

7. Putri WAR, Permana I. Hubungan antara Fungsi Keluarga dengan Kualitas Hidup Lansia. Mutiara Medika [Internet]. 2015 [cited 2020 Mar 28];11(1):1-7. Available from:

https://journal.umy.ac.id/index.php/mm/artic le/view/921.

8. Borhani M, Rastgarimehr B, Shafieyan Z, Mansourian M, Hoseini SM, Arzaghi SM, et al. Effects of predisposing, reinforcing and enabling factors on self-care behaviors of the patients with diabetes mellitus in the Minoodasht city, Iran. J Diabetes Metab Disord. [Internet]. 2015 Apr 14 [cited 2020 Jun 1];14:27. Available from: https://doi.org/10.1186/s40200-015-0139-0.
9. Mirza R. Memaksimalkan Dukungan Keluarga Guna Meningkatkan Kualitas Hidup Pasien Diabetes Melitus. Jurnal Jumantik [Internet]. 2017 [cited 2020 Jun 1];2(2):12-30. Available from: http://jurnal.uinsu.ac.id/index.php/kesmas/ar ticle/view/1122.

10. Nuraisyah F, Kusnanto H, Rahayujati TB. Family support and quality of life of diabetes mellitus patients in Panjaitan II public health center, Kulon Progo. Berita Kedokteran Masyarakat [Internet]. 2017 [cited 2020 Jun 1];33(1):55-66. Available from:

https://media.neliti.com/media/publications/ 196160-ID-dukungan-keluarga-dankualitas-hidup-pas.pdf.

11. Teli M. Kualitas Hidup Pasien Diabetes Melitus Tipe 2 Di Puskesmas Se Kota Kupang. Jurnal Info Kesehatan [Internet]. 2017 [cited 2020 Mar 28];15(1):119-134. Available from: https://jurnal.poltekeskupang.ac.id/index.ph p/infokes/article/view/133.

12. Kumar S. Type 1 diabetes mellitus-common cases. Indian Journal of Endocrinology and Metabolism [Internet]. 2015 [cited 2020 Mar 28];19(7):76-7. Available from: https://doi.org/10.4103/2230-8210.155409.

13. Setyawan FEB. Pendekatan Pelayanan Kesehatan Dokter Keluarga (Pendekatan Holistik Komprehensif). Sidoarjo: Zifatama Jawara; 2019.

14. Rodríguez-Sánchez E, Pérez-Peñaranda A, Losada-Baltar A, Pérez-Arechaederra D, Gómez-Marcos MÁ, Patino-Alonso MC, et al. Relationships between quality of life and family function in caregiver. BMC Fam Pract. [Internet]. 2011 Apr 15 [cited 2020 Mar 28];12:19. Available from: https://doi.org/10.1186/1471-2296-12-19.

15. Oktowaty S, Setiawati EP, Arisanti N. Hubungan Fungsi Keluarga Dengan Kualitas Hidup Pasien Penyakit Kronis Degeneratif di Fasilitas Kesehatan Tingkat Pertama. Jurnal Sistem Kesehatan [Internet]. 2018 [cited 2020 Mar 28];4(1):1-6. 
Available

from:

http://jurnal.unpad.ac.id/jsk_ikm/article/vie w/19180/0.

16. Dewianti NM. Fungsi keluarga, dukungan sosial dan kualitas hidup lansia di wilayah kerja Puskesmas III Denpasar Selatan. Public Health and Preventive Medicine Archive [Internet]. 2013 [cited 2020 Jun 10];1(2):1-6. Available from: https://ojs.unud.ac.id/index.php/phpma/articl e/view/7878.

17. Indrayani I, Ronoatmodjo S. Faktor-Faktor Yang Berhubungan Dengan Kualitas Hidup Lansia Di Desa Cipasung Kabupaten Kuningan Tahun 2017. Jurnal Kesehatan Reproduksi [Internet]. 2018 Nov [cited 2020 Jun 10];9(1):69-8. Available from: https://ejournal2.litbang.kemkes.go.id/index. php/kespro/article/view/892. 